\title{
DIRECT SEEDING IN ONTARIO
}

\author{
By George Bayly \\ Ontario Forestry Branch
}

D

RECT SEEDING is a method of reforesting waste land, but it is only one of the means which could be used. Given a tract of land the primary object is to establish the best possible forest cover at the lowest cost per acre. The safest way of doing this is by trial and error, but if this were attempted on a large scale it might prove very expensive. Consequently before setting out to reforest a large tract of land a series of three preliminary experiments should be carried out, and the results examined under the two headings-success and cost. This was done and the results were intended to answer the following questions:

I. What kind of seed to use?

II. What quantity of seed to use?

III. What would it cost per acre to plant?

\section{Preliminary Experiments I.}

In 1925 and 1926 a considerable amount of data was obtained on small areas and with various kinds of seed. In these preliminary tests great care was used to select sites which would be typical of larger tracts to be sown several years later.

Site.-The area selected and where all these experiments were carried on, was situated on Crown land about nine miles south of Parry Sound on the shores of the Georgian Bay, and was suitable in every way for the purpose. The general configuration of the ground was very rough and rocky, and the area had been burned over so recently that there was not much tree growth. The ground itself sloped slightly to the northwest, but the slope was not uniform throughout. Over three-quarters of the area the soil consisted of deep sandy loam, which became shallow, loamy sand and then sand overlying rock and boulders as the lower levels approached the lake shore. Small pockets of loam only occurred in depressions and crevices between the rocks.

Five per cent. of the area was swampy. The ground cover consisted of grass, which covered 70 per cent. of the area, and bracken, blueberry and sweetfern. There were also some patches of moss and some of wintergreen.

Seed-The two conditions upon which the feasibility of broadcast seeding on a large scale depended were success and cost. In these preliminary ex. periments, relative success of different kinds of seed was of primary importance. Three species of seed were used, white pine, red pine and jack pine. These were sown in seed spots. A measured quantity of seed was sown in each patch, a thimble containing 100 seeds being used. 
Light Conditions. The sites varied considerably with regard to light conditions. Fifty per cent. of the white pine was sown under poplar and birch 20 feet high with 500 trees to the acre. The remaining fifty per cent. was sown in open sunlight. Fifty per cent. of the red pine was also sown under poplar and birch 20 feet high. With 200 trees to the acre, the remainder was sown in open sunlight. Ninety per cent. of the Jack pine was sown in the open, ten per cent. under the same shade as the red pine.

Areas sown were as follows:

$\begin{array}{lllllll}\text { White pine } \ldots \ldots .1 / 5 & 1 / 10 & 1 / 10 & 1 / 10 & 1 / 10 & 1 / 10 \text { acres } \\ \text { Red pine } \ldots \ldots \ldots 1 / 10 & 1 / 10 & 1 / 10 & 1 / 10 & 1 / 10 & 1 / 4 \text { acres } \\ \text { Jack pine } \ldots \ldots \ldots 1 / 2 & 1 / 10 & & & & & \text { acres }\end{array}$

The above table will show that before arriving at any conclusion as to what kind of seed to sow a fairly comprehensive number of tests were made.

Methods Used on These Areas.

Method. A limited number of patches chosen at random on each plot were protected with a small fine mesh wire meat cover, in such a manner that small animals and birds would be unable to get at the seed. In order to insure this result, care was taken to press the edges of the wire into the ground. Where this was not practicable earth was heaped round the base so as to eliminate the possibility of having any creature gain an entrance under the cover. Finally, in order to keep the cover solidly in position, a ten inch spike was driven through the centre into the ground.

Method II. A certain limited number of patches chosen at random on each plot were protected with a flat piece of fly screen one square foot in size. This wire was only to be used as a protection for the seeds until germination had been completed, so that the sooner a screen disintegrated the better, once its purpose had been achieved. A three-inch nail was driven through the centre of the screen into the ground in order to keep it in position.

Summary of Results of the Above Methods.

White and Red Pine-The most important factor controlling the success for these two species on small areas seems to be small birds and rodents. Because-

(a) The average of patches with cover showed over four times as many seedlings as the average of uncovered patches.

(b) The plot which showed the best results of cover had over eleven times as many seedlings as the best uncovered plot.

(c) On some of the uncovered plots whose seeds had been treated with strychnine, a number of dead birds and mice were found. 
Jack Pine.

(a) The average number of patches with cover showed the same proportion of seedlings to the uncovered patches as the white and red pine.

(b) The average number of seedlings per patch on both covered and uncovered plots was four times as great as that of the white and red pine.

From the experiments so far carried out it was apparent that judged under the heading of success Jack pine had a slight advantage, but not enough to warrant seeding large areas to this species. In order to obtain more data it was decided to carry the preliminary experiments one step farther and sow a few rather larger areas.

Preliminary Experiments II.

This was done, and the same three species of seed were used in quantities per acre of one pound to three pounds.

Areas sown were as follows:

$\begin{array}{lrrrrrr}\text { White pine } \ldots \ldots \ldots \ldots 1 / 2 & 1 / 2 & 1 / 2 & 1 & 1 & 1 & \text { acres } \\ \text { Red pine } \ldots \ldots \ldots \ldots 1 / 2 & 1 / 2 & 1 / 2 & 1 / 2 & 1 & 1 & 2 \text { acres } \\ \text { Jack pine } \ldots \ldots \ldots \ldots \ldots .4 & 1 & 4 & & & & \text { acres }\end{array}$

In these larger areas different quantities of seed per acre were used, that is, one pound, two pounds and three pounds to the acre. All this seed, as well as the seed used in later broadcasting work was compensated to 100 per cent. germination.

The term compensated to 100 per cent. is explained as follows. As it was important to have approximate uniformity of germination per cent. for each pound of seed, in order that there should be the same number of good seeds per acre, the following method of obtaining it was adopted.

As the actual germination per cent. of the seed used was not 100 but averaged between 80 and 90 , sufficient seed was added per acre to bring it up to 100 . For example, if the seed used had a germination per cent. of 80 then $11 / 5 \mathrm{lbs}$. of seed would be sown per acre, and that amount would be considered to have a germination per cent. of 100 .

Recent investigations show that the percentage of germination obtained in germination tests is not proportional to the percentage obtained in the field, but they also show that the higher the quality of the seed the nearer the tree percentage corresponds with the results obtained by germination tests.*

Consequently, since the quality of the seed which was used was high and fairly uniform the lag of tree percentage behind the results obtained by germination tests would be approximately uniform on all areas sown.

* Toumey. 
The following table will show results obtained from the sowing of two or three areas of from one to four acres for each of the following species, white pine, red pine and jack pine.

\section{WHITE - RED - JACK PINE \\ Showing seedling count per acre over a period of 3 years, \\ * $1 \mathrm{lb}$. of seed being used per acre.}

$\begin{array}{lccc}\text { Count } & \text { White Pine } & \text { Red Pine } & \text { JACK Pine. } \\ \text { 1st year } & 1,066 & 700 & 21,000 \\ \text { 2nd year } & 400 & 150 & 5,000 \\ \text { 3rd year } & 9 & 0 & 3,600\end{array}$

The above results are typical of nearly all the small areas sown at a later date. The white and red pine are rather above the average for the second year, and the jack pine is exceptionally low for the third year, but for the most part as shown above the broadcasting of red and white pine on small areas has been unsuccessful.

The sowing of red pine was discontinued as being too expensive, but further experiments were carried on with white and jack pine in order to determine how much seed should be sown per acre to ensure a proper density in the young stand. Three pounds per acre was decided upon as being the maximum quantity that could be used without running the cost up to a prohibitive figure. Several acre plots were sown with the following result:

$\begin{array}{cc} & \text { Third Year Count } \\ \text { White Pine } & \text { Jack Pine } \\ 27 & 5,082\end{array}$

These results are on acre plots and serve only as a guide and cannot be compared with larger areas. The reason for this is not clear, but some larger areas have been sown to white pine and from the results obtained it is probable that the sowing of white pine on small areas is no indication of what this species will do on large areas, as the destruction of seed by rodents is so much greater when it is concentrated upon a one or two acre plot. It can be seen from the foregoing experiments that one pound of jack pine seed is sufficient when sown on small plots up to four acres.

According to general opinion, full seeding when properly done is more expensive than planting. That this is not always so, even when such a small quantity of seed as one pound per acre is used is indicated by the results shown by two experimental plantations carried out one on the same site as the seed spotting experiment, and the other on a similar site.

\footnotetext{
* Compensated to $100 \%$ germination.
} 
Preliminary Experiments: III.

(a) Devil's Elbow plantation, situated on the shores of the Georgian Bay, 9 miles south of Parry Sound, in the township of Cowper. This plantation consisted of 64 acres and was adjacent to some of the areas where broadcast seeding had been carried out. The site was so rocky that a spade could not be used, consequently to make a hole large enough for planting, mattocks were used. The stock planted was as follows:

$\begin{array}{lr}\text { White pine } & 2-1 \ldots \ldots \ldots \ldots \ldots \text { size } 5 \text {-in. } \\ \text { Red pine } & 2-1 \ldots \ldots \ldots \ldots \ldots \text { size } 6 \text {-in. } \\ \text { Jack pine } & 1-1 \ldots \ldots \ldots \ldots \text { size } 7 \text {-in. } \\ \text { trees were planted at a cost of } \$ 10.60 \text { per acre. }\end{array}$

(b) Lost Channel plantation, situated on the banks of the Pickerel river, 6 miles east of the village of Lost Channel, Township of Mowat, district of Parry Sound, area 170 acres. Same type of country as (a) but not quite so rough. 140,000 pine were planted at a cost of $\$ 9.99$ per acre.

Summary of Preliminary Experiments I, II and III.

(a) That the sowing of jack pine on small areas has proved a success.

(b) That the sowing of white and red pine on small areas has proved unsuccessful.

(c) That the planting of nursery stock on rocky sites has proved too expensive.

(d) That the sowing of $1 \mathrm{lb}$. of compensated jack pine seed per acre is sufficient.

Broadcast Seeding on Large Areas.

The first areas selected for these experiments were at the mouth of the Little Blackstone river which drains Crane Lake into the Georgian Bay about 22 miles south of the town of Parry Sound.

Site. The site for this area varied in some respects from the site where the preliminary experiments had been carried out. Perhaps the most noticeable difference was the almost entire absence of tree growth, what there was was so scattered as to be hardly worth considering.

However, there is no need of going into a detailed description of the various sites-these are all described in the reports*, it will be sufficient to say that the areas used for the comparatively large scale experiments in broadcast seeding were typical Parry Sound district rock. Some parts of the areas had a ground cover of grass, other parts moss and bracken. There was some tree growth, mostly poplar, white birch and pin cherry, 20 feet high. Most of the areas were characterized by large outcroppings of rock, some perfectly flat and many hundreds of square feet in extent with no vegetation

*Unpublished Reports. Reforestation, Ontario Forestry Branch. 
whatever. No portion of the ground was worked up in any manner as this would have increased the cost. As early seeding was important in order to allow the young seedlings to become established before the summer drouth, every effort was made to get on to the site by the last week in April, but as all the transportation was by boat this was not always possible owing to the large ice floes on the waters of the Georgian Bay. However, the earliest spring sowing was aimed at, and the first week in May always saw seeding under way.

The seed chosen as the best one for the purpose was jack pine. The reason for this is apparent when we examine the results obtained during the tests of the preceding three years. Compared with the red and white pine the results shown by jack pine broadcasting had shown distinct success. At the same time it was felt that jack pine as a permanent crop was not as desirable as, for instance, red pine. So it was decided that a combination of the two methods, broadcasting and planting, might be found practicable, planting red or white pine where possible and broadcasting the whole area with jack pine. The number of trees planted would depend on two factors, first-cost, second-quality of site. This combination planting and sowing would allow the red pine to have a three-year start, while the jack pine would come on forming a nurse crop.

There is no necessity of describing the different areas broadcasted and planted over a period of six years as in each case on this area the procedure was the same.

The first field work was undertaken in 1927 and was repeated each year for six years, each year the planting was done with red pine, except in 1929 when white pine was used. As soon as the planting was completed the area was seeded down to jack pine. One pound of seed compensated to 100 per cent germination to the acre.

One hundred transplants per acre were found to work out very well both as regards costs and quality of site, as it was found that however rough and rocky the site appeared to be, there were always enough good places where a spade could be used to plant 100 trees per acre.

The average cost per acre over the whole area of 1462 acres was $\$ 1.40$. The itemized figures in the following table will show how these were arrived at:

COST SHEET FOR PLANTING AND SEEDING, 1929 Labour:

Actual seeding and planting time:

$6511 / 2$ man hours @.25 ..........\$162.87

Lost time-none ................ 
Transportation:

Parry Sound to Little Blackstone and return (by boat)

24 man hours @.25 per hour .......\$\$ 6.00

Freight and express for trees and seed.. 7.75

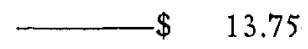

Camp Expenses:

Cook's wages-none

Board, 201 meals @ .25 ...............\$ 50.25

Cost per acre $\ldots \ldots \ldots \ldots 1.65$

Number of acres ..... 136.32

NOTE.-The cost of producing transplants, which is not included in the above should be reckoned at $\$ 4.00$ per thousand, and the cost of Jack Pine seed should be reckoned at $\$ 2.50$ per pound.

The examination or seed count of each area was carried out annually in August over a period of six years. In obtaining this per acre count the strip method was used. A binder twine line was pegged down diag. onally from corner to corner in as straight a line as possible, then a strip one foot wide was tallied, each yard being noted, whether it contained a seedling or not. The character of the ground cover for each yard was also noted. After this first diagonal strip was counted; other strips were run in an attempt to include all types of ground cover in as representative a manner as possible.

As it is impossible to give much of an idea of results except in tabulated or graphic form, the data obtained over a period of six years will be shown in that way.

\section{RESULTS}

JACK PINE BROADCASTING

Showing seedling count per acre over a period of six years.

$1 \mathrm{lb}$. of seed being used per acre.

1st year 2nd year 3rd year

Based on 30,170 sq. ft. Based on 23,120 sq. ft. Based on 10,425 sq. ft.

on 1462.86 acres

763

4 th year

Based on 12,465 sq. $\mathrm{ft}$.

on 291.12 acres on 1215.30 acres

393

5 th year

Based on 5,099 sq. ft. on 154.80 acres on 419.70 acres

941

6 th year

Based on 2,301 sq. ft. on 12.25 acres 
The figures for the different years were arrived at in the following manner:

A new area was seeded each year, so, under the heading "1st year" are six seedling counts for the years 1917, 1928, 1929, 1930, 1931 and 1932 for seed sown in May and counted in August for each year.

In the same manner under the heading "2nd year" are five counts, that is, counts for the years 1928,1929,1930, 1931 and 1932, for seed sown in May of one year and counted in August of the following year.

The following curve will show much more clearly the results obtained over the six year period.

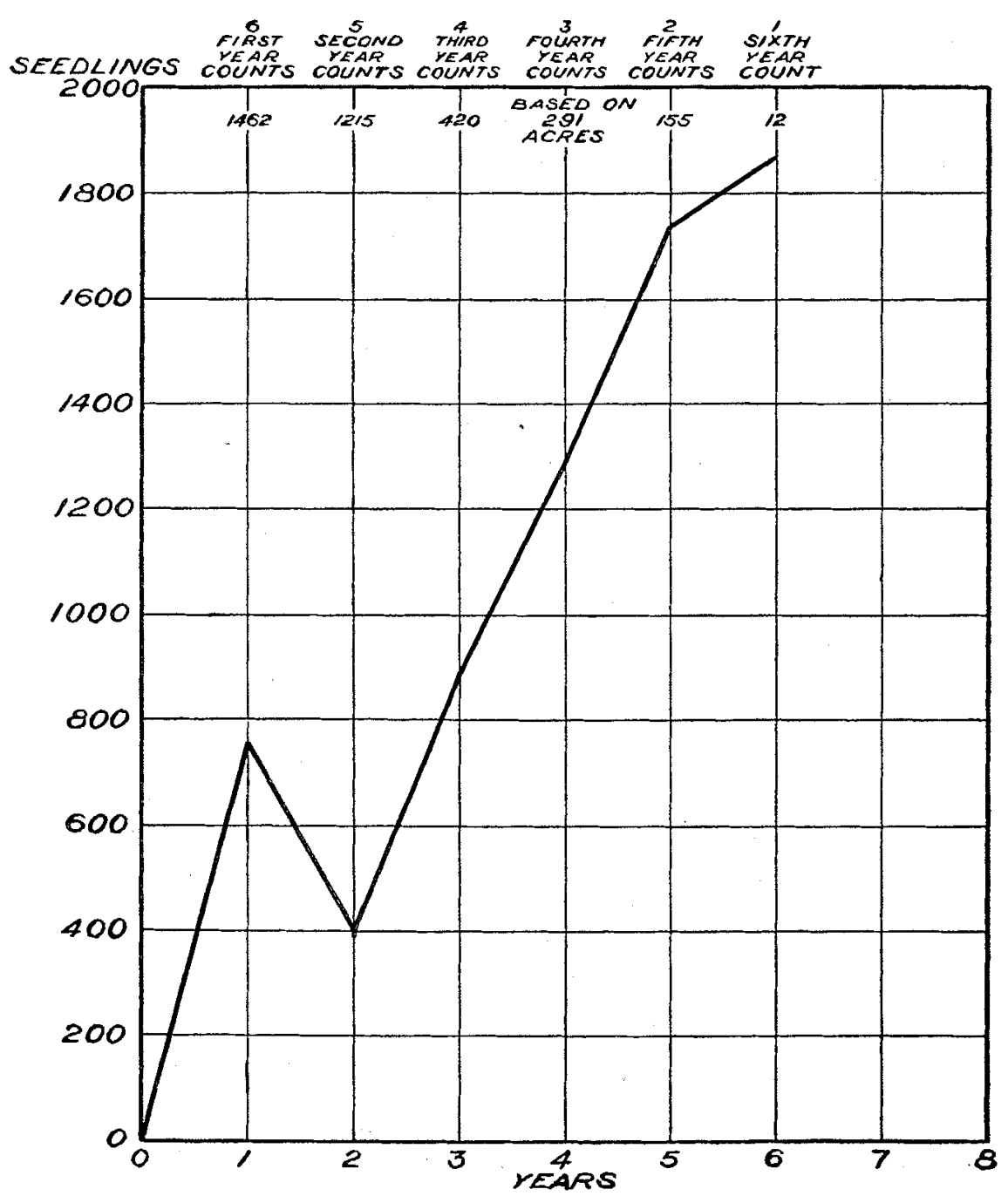

Graph showing seedling count per acre over a period of six years. 
There are two features with regard to this curve that might be remarked on. One is the steady increase of seedlings per acre with but one drop, and that in the second year. The second is the drop in seedlings per acre in the second year.

In examining the figures which give us the weighted average of 393 for the second year a marked decrease in number of seedlings is recorded every year. And as this second year figure includes counts for the years 1928, 1929, 1930, 1931 and 1932 it may be taken for granted that this drop in count is not due to seasonal variation.

What probably occurs is that there is a very high mortality after the first summer, and that, although delayed germination compensates to some extent, it does not do so enough to make up for the high mortality.

The other point mentioned, that is, the steady increase of seedlings per acre after the second year, is rather hard to account for.

There are various factors which influence a seedling count, and unless care is taken to reduce these factors to a minimum a very eratic and faulty result is liable to be obtained.

The position of the strip or strips is of the greatest importance, as a great variation in count is manifestly possible by changing the position of the strip from one year to the next. On the other hand, if a fixed position for the strip is selected and a count made on that strip alone over a period of years, the count, while possibly showing a more or less correct percentage rise or fall in number of seedlings each year, may be very far out as far as the total number of seedlings on the area is concerned.

In the attempt to get rid of the errors arising out of either of these methods, a combination of the two was adopted. One strip, between 60 and $70 \%$ of the total area counted was run straight diagonally across the plot and counted each year. Then two or three other shorter strips were counted, and the position of these was changed slightly each year, but enough to include all varieties of ground cover on the area.

There remain two other factors of primary importance which would have an influence on the number of seedlings, that is the presence of jack pine seed trees either now or in the past. As far as the present is concerned, jack pine is non existent, and there are no visible remains to show that it ever grew in that locality. Two fires have swept the area within fifteen years, the last one being in 1925 .

That leaves but one alternative to account for the increase in the number of seedlings from 393 in the second year to that of 1836 in the sixth year, and that is delayed germination.

Delayed Germination. The results of delayed germination can best be examined by recording height growth. This was done in 1932 when the 
6th year count was made. The height of every jack pine seedling tallied on the area sown in 1927 was recorded, as well as the height of red pine transplants. There were 216 seedlings six inches in height or less. These inch classes were divided as follows:

\section{HEIGHT CLASSES}

Counted 6 years after sowing.

$6 "$ and under.

$$
\begin{array}{ll}
1 " \ldots \ldots \ldots \ldots .0 & 4^{\prime \prime} \ldots \ldots \ldots \ldots .76 \\
2 \prime \ldots \ldots \ldots \ldots .38 & 5^{\prime \prime} \ldots \ldots \ldots \ldots .68 \\
3^{\prime \prime} \ldots \ldots \ldots \ldots .57 & 6^{\prime \prime} \ldots \ldots \ldots \ldots .57
\end{array}
$$

As this result was obtained by making a count showing height classes six years after sowing, it seems possible that some reports and articles on direct seeding written two or three years after sowing may be rather premature when they confess failure, or only partial success.

The following table, which shows the numbers per acre obtained in the different height classes, accentuates the results of delayed germination.

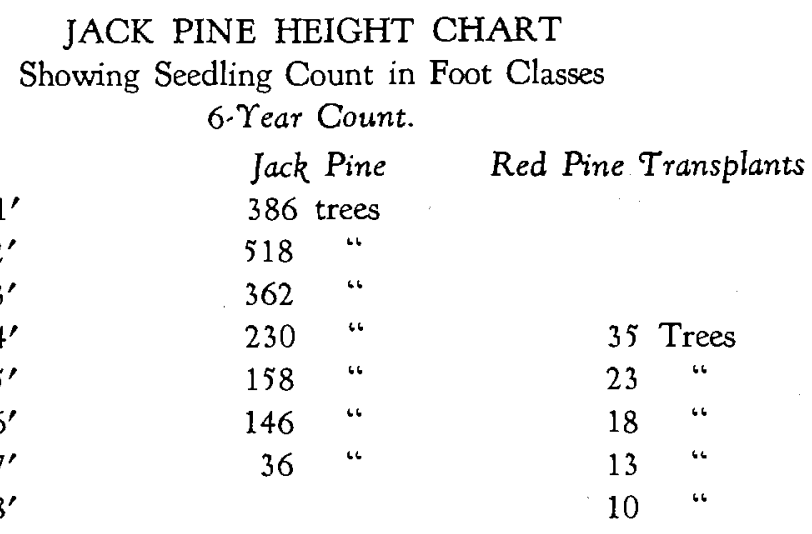

The record of the number of trees in each height class was tallied in inch classes in the field, but for the sake of clearness they have been shown here in foot classes.

The number of red pine shown is actually 99 per acre instead of 100 . The twelve trees that died were all between three and four feet in height.

Influence of Rainfall. One would expect seasonal variation in rainfall to have an influence on delayed germination over a period of six years. Yet on examining the height chart none can be noted. The figures which are shown in the next paragraph give 1928 as the wettest year. so one would expect the greatest number of seedlings in the 4 and 5 foot classes, but this is not the case, the greatest number occurring in the 1 and 2 foot classes, which would probably be the 1930 germination. 
The fact that the seeding was carried on over a period of six consecutive years shows that weather conditions do not affect jack pine seedlings to any marked degree. Statistics from the Meteorological Office in Toronto as regards precipitation give the following figures for the six year period between the years 1927 and 1932 inclusive in the Parry Sound district:

Average rainfall for June, July and August over a period of

48 years......... $7.97^{\prime \prime}$

Total rainfall for June, July and August of 1929 which was

the dryest year.......5.93"

This is 26 per cent under normal.

Total rainfall for June, July and August of 1928 which was

the wettest year.......11.79"

That is, 48 per cent over normal.

The following figures give a comparison between rainfall and number of seedlings per acre in the same year:

\begin{tabular}{|c|c|c|}
\hline Year & Total rainfall & $\begin{array}{c}\text { Number of Seedlings } \\
\text { per acre }\end{array}$ \\
\hline 1929 (dryest) & 5.93 & 570 \\
\hline 1928 (wettest) & 11.79 & 3,920 \\
\hline
\end{tabular}

The above figures when you examine them in relation to the curve showing seedling count per acre over a period of six years, do not seem to affect the result at all. But if you take 1928, which had the wettest season for June, July and August, by itself you can see that the second year seedling count was over six times that of the second year count for 1929 which was the dryest year.

Now if you examine the curve you can see that in spite of this very high seedling count for 1928 in the second year count, the point on the curve for the second year shows a very poor result over the entire period of six years. And as this second year figure includes counts for the years 1928, $1929,1930,1931$ and 1932, it may be taken for granted with greater certainty that this drop in count is not due to seasonal variation.

Ground Cover. There is one point which has not been touched on, and that is the relation which different types of ground cover bear towards the result of the seedling count. As the strips should include all variations in ground cover an examination of the relative percentages of each type with regard to the total area should be shown.

The important thing to show is the relationship between different types of ground cover and their influence, first-on the germination of seed and second-on delayed germination.

This can only be done by determining the percentage of area devoted to each type of ground cover and the corresponding seedling count. From that 
the trees on the area showing each type can be computed at 100 per cent. The following table will show this more clearly:

\begin{tabular}{|c|c|c|c|c|c|}
\hline \multicolumn{6}{|c|}{ 6th Year Count } \\
\hline & $\begin{array}{c}\text { Per- } \\
\text { centage } \\
\text { of }\end{array}$ & $\begin{array}{l}\text { Trees } \\
\text { on }\end{array}$ & $\begin{array}{c}\text { Trees on } \\
\text { Area } \\
\text { at }\end{array}$ & & \\
\hline $\begin{array}{l}\text { Ground Cover } \\
\text { Moss } \ldots \ldots \ldots\end{array}$ & $\begin{array}{l}\text { Area } \\
3\end{array}$ & $\begin{array}{l}\text { Strip } \\
12\end{array}$ & $\begin{array}{l}100 \% \\
400\end{array}$ & $\begin{array}{l}\text { Largest } \\
5^{\prime} 4^{\prime \prime}\end{array}$ & $\underset{1.1 "}{\text { Smallest }}$ \\
\hline Sand $\ldots \ldots \ldots$ & 1 & 3 & 300 & $4^{\prime} 0^{\prime \prime}$ & $4^{\prime} 0^{\prime \prime}$ \\
\hline Moss and Bracken & 18 & 52 & 288 & $4^{\prime} 5^{\prime \prime}$ & $.2 \prime \prime$ \\
\hline Grass ......... & 37 & 21 & 56 & $4^{\prime} 1^{\prime \prime}$ & $.2 \prime \prime$ \\
\hline$\ldots \ldots \ldots$ & 15 & 7 & 46 & $6^{\prime} 4^{\prime \prime}$ & $4^{\prime} 0^{\prime \prime}$ \\
\hline Rock Crevices ... & 25 & 2 & 8 & $6^{\prime} 0^{\prime \prime}$ & $.4 "$ \\
\hline Swamp ....... & 1 & 0 & 0 & 0 & 0 \\
\hline
\end{tabular}

The heading "Trees on Area at 100 per cent" requires some explanation. For instance, "Moss" covered 3 per cent of the area and contained 12 trees. If the whole area, that is 100 per cent, had been "Moss" it would at the same ratio have contained 400 trees. And so on with the other types of ground cover.

There are one or two points about the results shown in this table that should be brought out:

(1) The area of sand is very small, only 1 per cent. The reason for this is that there was only one small piece of sand which was bare of vegetation. The strip was run through it, and took in $33 \mathrm{sq} . \mathrm{ft}$.

(2) The area of moss is also small, but it was difficult to find moss not in conjunction with bracken.

(3) The germination and sand must have occurred in one year only as all the seedlings were of the same height, that is about 4 feet high. It is probable that germination took place in 1928 which was the wettest year.

(4) It appears that delayed germination occurs to a much greater extent where there is good ground cover.

Note-Moss and Bracken, and Grass,--both of these types have smallest seedlings 2 inches high.

- Sand and Litter,-both of these types have smallest seedlings, 4 feet high.

In order to bring out this point more clearly it would be as well to show the percentage of each height class for each type of ground cover in tabulated form. 


\author{
Table Showing Percentages \\ in each Foot Height Class \\ for each Type of Ground Cover. \\ Percentages up to
}

\begin{tabular}{|c|c|c|c|c|c|c|}
\hline $\begin{array}{l}\text { Ground Cover } \\
\text { Moss } \ldots \ldots \ldots \ldots\end{array}$ & $1 \mathrm{ft}$. & $\begin{array}{c}2 \mathrm{ft} . \\
8\end{array}$ & $\begin{array}{l}3 \mathrm{ft} . \\
42\end{array}$ & $\begin{array}{l}4 \mathrm{ft} . \\
8\end{array}$ & $\begin{array}{c}5 \mathrm{ft} . \\
8\end{array}$ & $\begin{array}{l}6 \mathrm{ft} . \\
34\end{array}$ \\
\hline Sand $\ldots \ldots \ldots \ldots$ & & & & 100 & & \\
\hline M. $\&$ B.$\ldots \ldots$ & 20 & 46 & 14 & 2 & 18 & \\
\hline Grass $\ldots \ldots \ldots \ldots$ & 21 & 21 & 26 & 16 & 16 & \\
\hline Litter $\ldots \ldots \ldots \ldots$ & & & & 29 & 29 & 13 \\
\hline Rock $\ldots \ldots \ldots \ldots$ & 20 & & & & & \\
\hline
\end{tabular}

From the above table it appears that delayed germination occurs more in moss and bracken, and grass than in other types of ground cover.

The result in sand was probably due to the fact that there was very little moisture, and that the seed did not germinate until a favourable season came along, which was undoubtedly 1928 , the wettest year.

SUMMARY.

The experiment has only been carried on for six years, but there are, nevertheless, some definite indications of the final results. These are as follows:

(1) That the broadcast sowing of jack pine is a success.

(2) That delayed germination is one of the most important factors in this success.

(3) That owing to the high percentage of delayed germination, weather conditions have only a minor effect on the seeding of jack pine.

(4) That moss, sand, and bracken are most favourable for the establishment of jack pine seedlings.

(5) That grass, whilst not favourable for the establishment of seedlings, shows the highest percentage of delayed germination.

(6) That the planting of red and white pine transplants in conjunction with the sowing of jack pine seed has proved a success, and that the red pine transplants maintain their three year start for at least six years.

(7) That plantations of transplants are a success, as shown by the results of a count taken three years after planting which gave a survival of 96 per cent, but that planting of these rocky burned over lands is too costly an operation to be carried out on a large scale. 